\title{
PEMBERDAYAAN KELOMPOK INFORMASI MASYARAKAT DI DESA DANASARI KECAMATAN CISAGA KABUPATEN CIAMIS
}

\author{
EMPOWERMENT OF COMMUNITY INFORMATION GROUPS \\ IN DANASARI VILLAGE, CISAGA DISTRICT, CIAMIS REGENCY
}

\author{
Kiki Endah*, Erlan Suwarlan, Aditiyawarman \\ Fakultas Ilmu Sosial Dan Ilmu Politik Universitas Galuh \\ *Email: kiki_spt@yahoo.co.id
}

(Diterima 29-08-2021; Disetujui 15-09-2021)

\begin{abstract}
ABSTRAK
Pengabdian ini bertujuan untuk mewujudkan masyarakat yang aktif, peduli, peka mengenai pentingnya keberadaan lembaga atau kelompok informasi masyarakat sebagai mitra pemerintah dalam penyebarluasan, sosialisasi dan informasi pembangunan kepada masyarakat. Selain itu, pentingnya keberadaan Kelompok Informasi Masyarakat sebagai mediator komunikasi informasi pembangunan secara timbal balik dan berkesinambungan serta menjadi forum media untuk pelayanan komunikasi dan informasi pemerintah dan pembangunan serta sebagai wahana informasi dan komunikasi antara anggota kelompok informasi masyarakat dengan pemerintah Desa Danasari Kecamatan Cisaga Kabupaten Ciamis. Permasalahan mitra yang muncul dapat diidentifikasikan sebagai berikut: 1) Minimnya pemahaman masyarakat berkaitan kelompok informasi masyarakat di desa; 2) Sebagian masyarakat belum sadar akan pentingnya informasi untuk dapat meningkatkan daya saing ekonomi; 3) Minimnya kemampuan dan pengetahuan masyarakat dalam membentuk dan mengelola kelompok informasi masyarakat. Adapun tujuan dari pengabdian masyarakat yang dilaksanakan, yaitu: a) Memberikan pemahaman pentingnya kelompok informasi masyarakat sebagai nilai tambah masyarakat dan membangun kesadaran akan pentingnya informasi. b) Melaksanakan sosialisasi pemberdayaan kelompok informasi masyarakat guna meningkatkan kemampuan dalam pembentukan kelompok informasi masyarakat. c) Memberikan solusi berdasarkan kajian akademik atas kebutuhan dan persoalan yang dihadapi masyarakat berkaitan pembentukan dan pelaksanaan kelompok informasi masyarakat. Adapun solusi yang diberikan adalah memberikan pemahaman serta pendampingan dalam pembentukan Kelompok Informasi Masyarakat. Metode yang digunakan dalam pengabdian ini adalah dengan cara pemberian sosialisasi, pendampingan dalam pembentukan kelompok informasi masyarakat. Dimana tahapan dalam pengabdian ini adalah: 1) sosialisasi; 2) pemahaman mengenai kelompok Informasi Masyarakat; 3) Pendampingan; 4) Evaluasi dan tindak lanjut.
\end{abstract}

Kata Kunci : Pemberdayaan, Kelompok, Informasi Masyarakat

\section{ABSTRACT}

This service aims to create an active, caring, sensitive community about the importance of the existence of community information institutions or groups as government partners in disseminating, socializing and developing development information to the community. In addition, the importance of the existence of the Community Information Group as a mediator of reciprocal and sustainable development information communication as well as being a media forum for government and development communication and information services as well as a vehicle for information and communication between members of the community information group and the government of Danasari Village, Cisaga District, Ciamis Regency. Partner problems that arise can be identified, as follows: 1) Lack of community understanding regarding community information groups for the village; 2) Some people are not aware of the importance of information to increase economic competitiveness; 3) The community's lack of ability and knowledge in forming and managing community information groups. The objectives of community service that will be carried out are: To provide an understanding of the importance of community information groups as added value to the community and to build awareness of the importance of information. Carrying out socialization of community information group empowerment in order to improve the ability to form community information groups. Provide solutions based on academic studies of the needs and problems faced by the community related to the formation and implementation of community information groups. The method used in this service is by assisting in the formation of community information groups. Where the stages in this service are: 1) socialization; 2) understanding of the Community Information group; 3) Mentoring; 4) Evaluation and follow-up.

Keywords : Empowerment, Community Information Group 
Pemberdayaan Kelompok Informasi Masyarakat di Desa Danasari Kecamatan Cisaga Kabupaten Ciamis

Kiki Endah, Erlan Suwarlan, Aditiyawarman

\section{PENDAHULUAN}

Lahirnya Undang-Undang Nomor 14 Tahun 2008 tentang Keterbukaan Informasi Publik telah memberikan jaminan kepada masyarakat dalam memperoleh informasi seluas luasnya. Dalam undang-undang tersebut dinyatakan bahwa informasi merupakan kebutuhan pokok setiap orang bagi pengembangan pribadi dan lingkungan sosialnya serta merupakan bagian penting bagi ketahanan nasional.

Keterbukaan informasi memberikan manfaat yang besar terhadap kemajuan masyarakat yang berada di pinggiran maupun di pedesaan. Apalagi dengan pesatnya perkembangan di bidang teknologi memberikan kemudahan dalam mendapatkan informasi yang dibutuhkan untuk memecahkan persoalan yang dihadapi pada kehidupan bermasyarakat. Hal ini seperti yang diutarakan Septaning Rena Julika (2016) Keterbukaan Informasi Publik akan menggerakkan masyarakat untuk berperan aktif dan ikut serta dalam pelaksanaan pembangunan, sehingga pembangunan benar-benar berbicara tentang kepentingan rakyat sehingga menjadi tugas bersama antara masyarakat dan pemerintah dalam menyalurkan informasi melalui media apapun, baik secara tertulis ataupun secara lisan.

Selain itu, perkembangan informasi memberikan kesempatan kepada masyarakat untuk berpartisipasi pada pelaksanaan pembangunan di berbagai bidang kehidupan, salah satunya dengan mengangkat potensi sumber daya lokal yang dimiliki daerah maupun desa sehingga memberikan dampak positif bagi kesejahteraan dan kemakmuran masyarakat setempat. Hal ini sejalan yang disampaikan Hasan (2010) bahwa kecanggihan sistem informasi yang berlandaskan keterbukaan memudahkan masyarakat untuk mengakses berbagai permasalahan serta solusi permasalahan tersebut di berbagai belahan dunia sehingga memberikan perubahan dan kemajuan kesejahteraan masyarakat.

Keterbukaan informasi pada masyarakat pedesaan diperlukan untuk membuka wawasan dalam berfikir kritis, inovatif dalam membangun kemajuan desa. Pemberdayaan kelompok informasi masyarakat tersebut sebagai jembatan informasi antara pemerintah dengan masyarakat. Selain itu, kelompok ini sebagai penyambung lidah masyarakat yang dikemas secara bijak ke dalam wadah media elektronik sebagai kritik membangun untuk kemajuan dan kesejahteraan masyarakat desa. Dengan pemberdayaan dapat mewujudkan kemandirian masyarakat dimana hal ini sejalan yang dikatakan (Endah, 2020) bahwa kemandirian masyarakat sebagai suatu keadaan dimana masyarakat memiliki kemampuan untuk berfikir, kemudian memutuskan dan menjalankan sesuatu yang dirasakan bermanfaat untuk memecahkan permasalahan melalui kemampuan dan kekuatan yang dimiliki 
masyarakat sendiri. Pemberdayaan menurut Sumaryadi (2005) merupakan pemberian kemampuan kepada masyarakat untuk lebih mandiri, maju demi kesejahteraan sehingga perlu ada penguatan kelembagaan masyarakat. Selanjutnya Mubyarto dalam Awang (2010) bahwa penekanan pemberdayaan yaitu dengan mengembangkan potensi sumber daya masyarakat desa sehingga dapat menciptakan usaha sesuai dengan kemampuan yang ada dalam diri masyarakat tersebut diikuti dengan perkembangan ilmu, teknologi dan informasi.

Untuk mewujudkan kelompok informasi masyarakat, maka Menteri Komunikasi dan Informatika Republik Indonesia mengeluarkan Peraturan Menteri Nomor 08/PER/M.KOMINFO/6/2010 tentang Pedoman Pengembangan dan Pemberdayaan Lembaga Komunikasi Sosial. Dimana dikatakan bahwa Lembaga Komunikasi Perdesaan adalah Kelompok Informasi Masyarakat atau kelompok sejenis lainnya, selanjutnya disingkat KIM, yang dibentuk oleh masyarakat, dari masyarakat dan untuk masyarakat secara mandiri dan kreatif yang aktivitasnya melakukan kegiatan pengelolaan informasi dan pemberdayaan masyarakat dalam rangka meningkatkan nilai tambah. Hal ini sejalan yang dikatakan (Alfando W.S, 2013) bahwa "Kelompok Informasi Masyarakat dibentuk untuk menjadikan masyarakat peka, aktif dan terbuka terhadap semua informasi. Hal ini ditegaskan oleh (Faris dan Muyasaroh, 2008) bahwa Kelompok Informasi Masyarakat merupakan agen informasi, memiliki peran aktif menyebarkan informasi yang diperlukan, dibutuhkan serta diketahui masyarakat, sehingga masyarakat dapat melakukan langkah antisipatif yang bermanfaat untuk menopang aktivitas mereka. Selain itu menurut

Kenyataannya masyarakat pada daerah kawasan pedesaan dalam mendapatkan kemudahan informasi yang cepat, mudah, terpercaya serta sesuai dengan permasalahan yang dihadapi dalam kehidupan masih kurang. Hal ini disebabkan edukasi kepada masyarakat akan pentingnya informasi yang diperoleh melalui teknologi informasi yang berkembang saat ini masih kurang, kemampuan sumber daya manusia lokal desa yang masih kurang dalam mengelola teknologi informasi digital untuk kepentingan keterbukaan informasi bagi masyarakat, serta akses jaringan yang masih belum merata pada daerah kawasan pedesaan.

Melihat permasalahan tersebut, maka perlu ada kemandirian melalui pemberdayaan masyarakat dalam pembentukan lembaga yang dapat menjembatani penyebaran informasi kepada masyarakat. Sehingga berdasarkan hal di atas, maka dilakukan kegiatan pengabdian mengenai Pemberdayaan Kelompok Informasi Masyarakat di Desa Danasari Kecamatan Cisaga Kabupaten Ciamis yang diharapkan dengan adanya kegiatan pengabdian ini 
masyarakat mampu mengoptimalkan manfaat keberagaman informasi bagi kepentingan kehidupan mereka dan bagi kemajuan serta kesejahteraan masyarakat desa.

\section{BAHAN DAN METODE}

Adapun metode yang digunakan dalam pengabdian ini adalah dengan cara pemberian pemahanan, sosialisasi dan pendampingan dalam pembentukan kelompok informasi masyarakat. Dimana tahapan dalam pengabdian ini adalah : 1) pemahaman; 2) sosialisasi mengenai kelompok Informasi Masyarakat; 3) Pendampingan; 4) Evaluasi dan tindak lanjut.

\section{HASIL DAN PEMBAHASAN}

Langkah awal kegiatan pengabdian adalah observasi awal yang kemudian dilanjutkan dengan identifikasi permasalahan mitra. Sasaran dalam pengabdian ini adalah masyarakat dan pemerintah Desa Danasari Kecamatan Cisaga Kabupaten Ciamis. Sebelum kegiatan pengabdian, dilakukan persiapan mencari referensi, penyiapan materi dan pemenuhan administrasi perizinan kegiatan pengabdian.

Dalam pelaksanaan pengabdian yang dilakukan dengan pemaparan materi berkaitan Sosialisasi Pemberdayaan Kelompok Informasi Masyarakat dimana isi dari kegiatan tersebut membahas mengenai keorganisasian, tujuan dan makna KIM yang harus diketahui pemerintah desa sebagai penyelenggara pemerintahan serta masyarakat sebagai subyek yang menjalankan segala kegiatan yang terwadah dalam organisasi yang lahir dari dan untuk masyarakat. Dampak yang dapat diberikan dengan terbentuknya KIM terhadap masyarakat desa menjadi bagian dari tujuan pemberdayaan KIM.

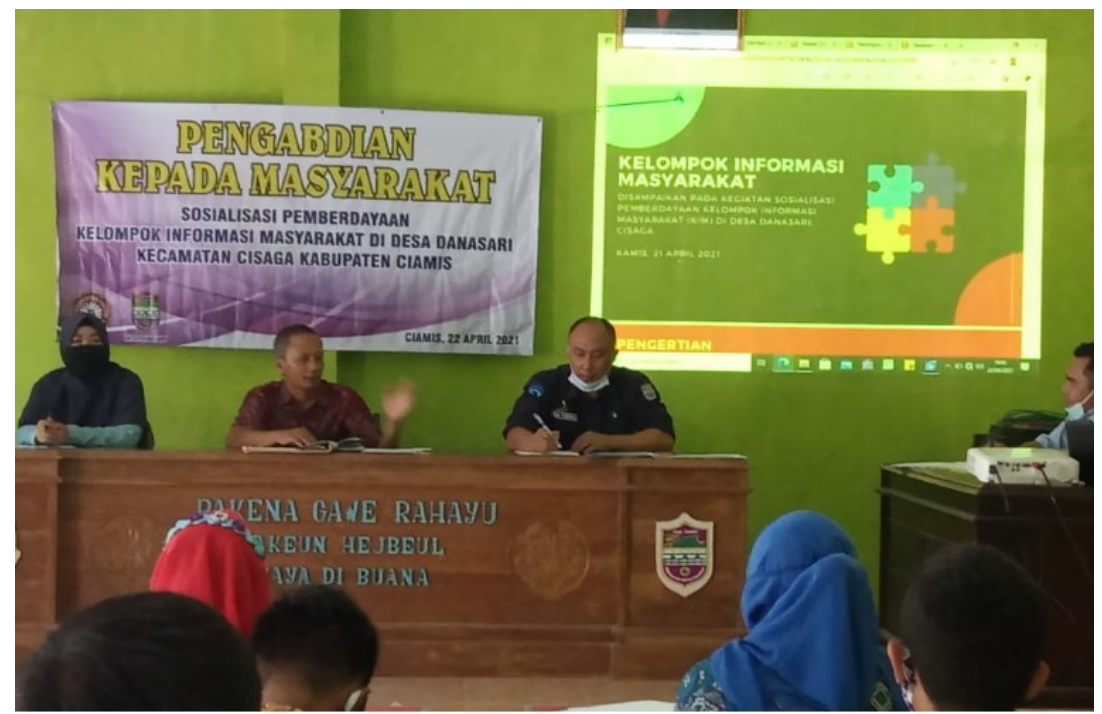

Gambar 1. Sosialisasi Pemberdayaan KIM di Desa Danasari 
Sebagai pemateri dalam sosialisasi pemberdayaan Kelompok Informasi Masyarakat adalah anggota tim pengabdian kepada Masyarakat yang diwakili oleh Dosen FISIP Universitas Galuh yaitu saudara Dr. Erlan Suwarlan, S.IP., M.I.Pol. serta menghadirkan narasumber dari Dinas Komunikasi dan Informatika Kabupaten Ciamis. Kegiatan pengabdian ini mendapat tanggapan positif dari seluruh peserta yang hadir sebanyak 15 orang. Dalam pelaksanaan sosialisasi ini banyak feetback dan pertanyaan yang disampaikan masyarakat dan juga pemerintah desa berkaitan pemberdayaan KIM tersebut.

Pengabdian kepada Masyarakat (PKM) merupakan bagian dari tridharma perguruan tinggi yang diimplementasikan oleh FISIP Universitas Galuh, melalui Tim pendampingan desa untuk memberikan pengetahuan dan pemahaman berkaitan pentingnya keberadaan Kelompok Informasi Masyarakat (KIM) karena KIM merupakan lembaga atau kelompok yang dibentuk oleh masyarakat, dari masyarakat dan untuk masyarakat secara mandiri dan kreatif dimana aktifitasnya adalah melakukan kegiatan pengelolaan informasi dan pemberdayaan masyarakat dalam rangka meningkatkan nilai tambah. Keberadaan KIM memiliki manfaat dan fungsi yang sangat strategis di tengah masyarakat yakni sebagai sumber informasi masyarakat dan sebagai kontrol sosial dengan dukungan kuat dari pemerintah desa.

Dalam kegiatan sosialisasi pemberdayaan KIM muncul beberapa permasalahan yang dihadapi pemerintah desa dalam proses pelaksanaan KIM dimana masih kurang baiknya jaringan internet sehingga menghambat akses penyaluran informasi kepada masyarakat desa. Serta kurangnya peran masyarakat desa untuk berpartisipasi ke dalam lembaga atau organisasi yang diwadahi oleh pemerintah desa.

Adapun output dari kegiatan pengabdian kepada masyarakat melalui sosialisasi pemberdayaan Kelompok Informasi Masyarakat di desa, yaitu: terbentuknya pemahamanan masyarakat akan pentingnya keberadaan kelompok Informasi Masyarakat, serta terbentuknya kelompok informasi masyarakat di Desa Danasari sebagai mitra pemerintah dalam penyebarluasan, sosialisasi dan diseminasi informasi pembangunan kepada masyarakat sebagai mediator komunikasi informasi pembangunan secara timbal balik dan berkesinambungan serta menjadi forum media untuk pelayanan komunikasi dan informasi pemerintah dan pembangunan. Selain itu, dengan terbentuknya KIM dapat sebagai wahana informasi antar anggota KIM, dari KIM kepada pemerintah dan dari pemerintah kepada masyarakat, KIM sebagai mitra dialog dengan pemerintah dalam merumuskan kebijakan publik. KIM sebagai sarana peningkatan literasi anggota kim dan 
masyarakat di bidang informasi dan media masa, dan KIM sebagai lembaga yang memiliki nilai ekonomi.

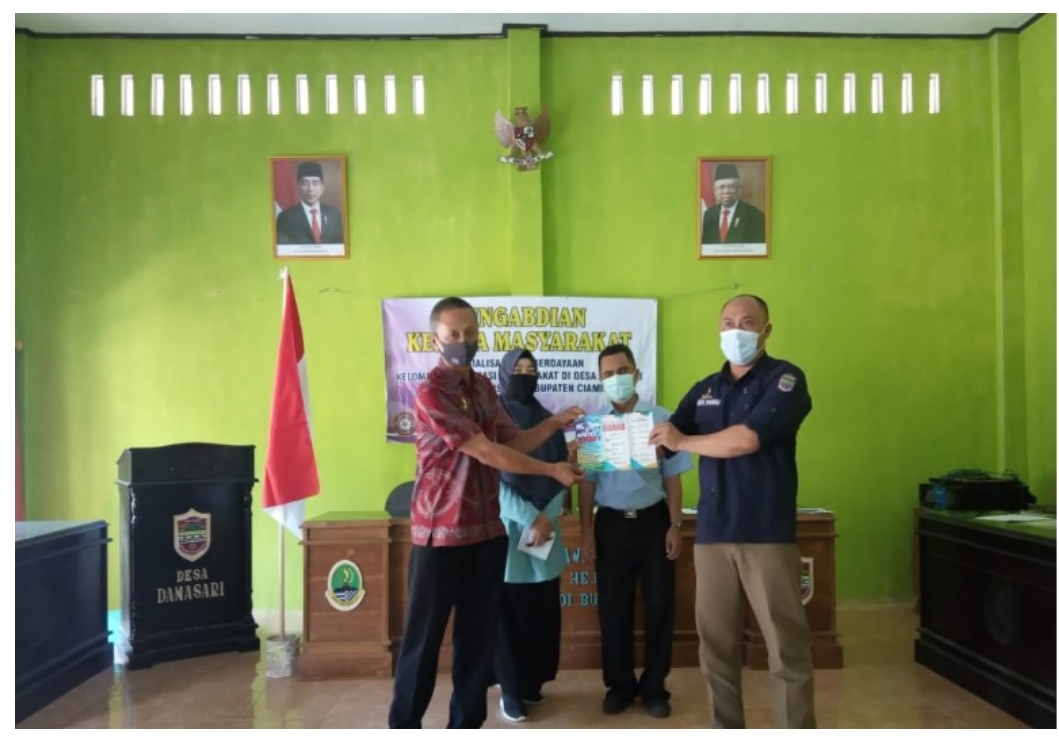

Gambar 2. Penyerahan cindera mata kepada Kepala Desa Danasari

Pengabdian kepada Masyarakat $(\mathrm{PkM})$ yang dilakukan ini sebagai bagian dari tridharma perguruan tinggi yang diimplementasikan oleh FISIP Universitas Galuh, melalui tim pendampingan desa untuk memberikan pengetahuan dan pemahaman berkaitan pentingnya keberadaan Kelompok Informasi Masyarakat (KIM) karena KIM merupakan lembaga atau kelompok yang dibentuk oleh masyarakat, dari masyarakat dan untuk masyarakat secara mandiri dan kreatif dimana aktifitasnya adalah melakukan kegiatan pengelolaan informasi dan pemberdayaan masyarakat dalam rangka meningkatkan nilai tambah. Keberadaan KIM memiliki manfaat dan fungsi yang sangat strategis di tengah masyarakat yakni sebagai sumber informasi masyarakat dan sebagai kontrol sosial dengan dukungan kuat dari pemerintah desa.

Hal ini sejalan dengan yang disampaikan oleh Herman (2007) bahwa keberhasilan pemberdayaan memerlukan keterlibatan dan hubungan yang bersifat sinergis antar segenap komponen (stakeholder) dengan fungsi dan peran masing-masing sebagai bagian dari sistem, baik masyarakat, pemerintah maupun pihak terkait lainnya.

Pembentukan kelompok informasi masyarakat tersebut tidak lepas dari landasan pada Peraturan Menteri Nomor 08/PER/M.KOMINFO/6/2010 tentang Pedoman Pengembangan dan Pemberdayaan Lembaga Komunikasi Sosial. Dimana dijelaskan bahwa Lembaga Komunikasi Perdesaan adalah Kelompok Informasi Masyarakat atau kelompok sejenis lainnya, selanjutnya disingkat KIM, yang dibentuk oleh masyarakat, dari masyarakat dan untuk masyarakat secara mandiri dan kreatif yang aktivitasnya melakukan kegiatan 
pengelolaan informasi dan pemberdayaan masyarakat dalam rangka meningkatkan nilai tambah.

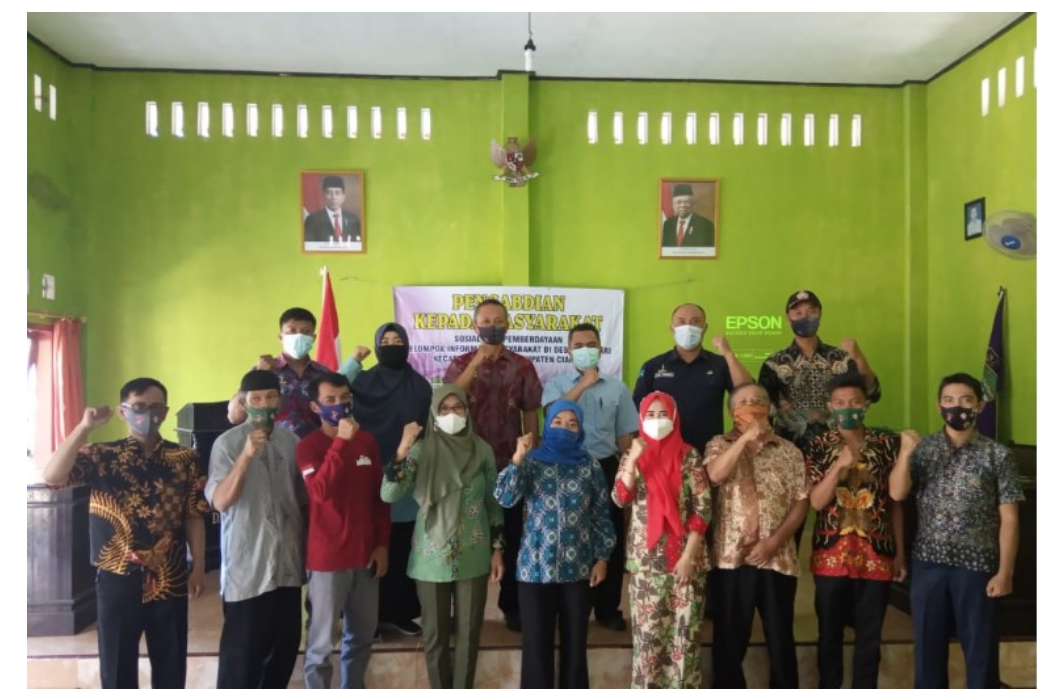

Gambar 2. Foto bersama dengan peserta kegiatan pemberdayaan KIM Desa Danasari

\section{KESIMPULAN DAN SARAN}

Berdasarkan hasil evaluasi pelaksanaan sosialisasi pemberdayaan kelompok Informasi masyarakat bahwa pemerintah desa dan masyarakat di Desa Danasari Kecamatan Cisaga Kabupaten Ciamis yaitu bertambahnya pemahaman mengenai pentingnya keberadaan lembaga atau kelompok informasi masyarakat sebagai mitra pemerintah dalam penyebarluasan, sosialisasi dan informasi pembangunan kepada masyarakat. Selain itu pentingnya keberadaan Kelompok Informasi Masyarakat sebagai mediator komunikasi informasi pembangunan secara timbal balik dan berkesinambungan serta menjadi forum media untuk pelayanan komunikasi dan informasi pemerintah dan pembangunan.

Saran bagi pemerintah daerah adalah memberikan fasilitas jaringan internet lebih baik dan memadai sehingga masyarakat yang tergabung dalam kelompok informasi dapat menyampaikan dan menyebarkan informasi-informasi positif untuk kemajuan pembangunan desa.

\section{DAFTAR PUSTAKA}

Alfando W.S, J. (2013). Peranan Kelompok Informasi Masyarakat ( KIM ) dalam Mewujudkan Desa Mandiri di Desa Sidomulyo Kec. Anggana Kutai Kartanegara. EJournal Ilmu Komunikasi, 1(2), 109-125.

Awang, Azam. 2010. Implementasi Pemberdayaan Pemerintahan Desa. Pustaka Pelajar.Yogyakarta.

Endah, K. (2020). Pemberdayaan Masyarakat : Menggali Potensi Lokal Desa. Moderat: 
Jurnal Ilmiah Ilmu Pemerintahan, 6(1), 135-143.

https://jurnal.unigal.ac.id/index.php/moderat/article/view/3319/2914

Faris dan Muyasaroh, S. (2008). Peran Kelompok Informasi Masyarakat ( KIM) Sebagai

Sumber. 1, 1-12.

Hasan, Erlina. 2010. Komunikasi Pemerintahan. Cetakan kedua. Bandung : Refika Aditama.

Mardikanto, Totok, and, Soebianto, Poerwoko. 2013. Pemberdayaan Masyarakat Dalam Perspektif kebijakan Publik. Alfabeta. Surakarta.

Peraturan Menteri Nomor 08/PER/M.KOMINFO/6/2010 tentang Pedoman Pengembangan dan Pemberdayaan Lembaga Komunikasi Sosial.

Septaning Rena Julika, I. I. P. (2016). MENDORONG PEMBANGUNAN DESA

Septaning Rena Julika, Irma Irawati P Fakultas Ilmu Sosial dan Ilmu Politik Universitas Wiraraja Sumenep. Publik Corner, 11.

Sumaryadi. 2005. Perencanaan Pembangunan Daerah Otonom dan Pemberdayaan Masyarakat. Jakarta: CV Citra Utama.

Undang-Undang Nomor 14 Tahun 2008 tentang keterbukaan informasi publik 